\title{
Understanding and Attitudes towards Moral and Civic Education among Primary School Teachers in Hong Kong
}

\author{
Wing Yee Lo \\ Faculty of Education and Social Work, The University of Sydney \\ NSW 2006, Australia \\ Tel: 61-2-9351-6355 E-mail: wing.yee.lo@edfac.usyd.edu.au
}

\begin{abstract}
Acknowledgements
My sincere thanks are extended to Professor Wing On Lee for his supervision in this research project.
\end{abstract}

\begin{abstract}
Moral and Civic Education (MCE) was highlighted in the 2000 curricular reform proposals in Hong Kong. This paper attempts to investigate primary school teachers' understanding and attitudes towards MCE in Hong Kong. It aims to understand whether and how the proposed curriculum of MCE is practiced in the school. Six teachers from a primary school were interviewed and the curriculum documents of the school were analyzed. The findings indicated that all of the interviewees lacked comprehensive understanding of MCE but they generally had high degree of concern towards the implementation of moral and civic development in the school. They were also receptive towards new ideas and teaching approaches in MCE. Further analysis showed that school-based curriculum and teachers' perceptions were the contradictory factors affecting teachers' implementation of MCE.
\end{abstract}

Keywords: Civics education, Citizenship education, Moral education, Primary curriculum, Teacher understanding, Teacher attitude

\section{Introduction}

Hong Kong had become a British colony since 1842 by the Treaty of Nanking. It was returned to Chinese sovereignty on the 1st of July in 1997. The issue of civics education especially national identity was almost unmentioned during the period of its colonial history. When this study was conducted, Hong Kong has been returned to the sovereignty of People's Republic of China for almost ten years. In this ten-year period after the 1997 handover, there has been growing awareness of the need for the Hong Kong educational system about the strengthening of civics and citizenship education. The role of the Hong Kong government in promoting civics and citizenship education shifted from a passive role to a supporting role in post-1997 educational changes.

In 2000, the Education Commission of the Hong Kong Special Administrative Region first proposed civics and citizenship education, namely Moral and Civic Education (MCE), as one of four key learning and teaching tasks of curricular reform in a consultation document (Education Commission, 2000). In the two following curriculum documents published afterwards, the Curriculum Development Council (2001, 2002a) put it at the top of five essential learning experiences for whole-person development in the curriculum guides. MCE was also highlighted with details in the subsequent curriculum guide entitled Basic Education Curriculum Guide - Building on Strengths (Primary 1 Secondary 3) in 2002. The components of civics and morality, the recommendations of teaching strategies and the assessment principles were clearly stated in the curriculum guide. During the period of curricular reform from 2001 to 2006, schools were encouraged to integrate the five priority values including perseverance, respect for others, responsibility, national identity and commitment (Curriculum Development Council, 2002a, Booklet 3A, pp. 2-4) into the school mission.

In order to strengthen the promotion of MCE, the Education and Manpower Bureau (EMB) put a great deal of effort into the provision of resource support and professional training. With a huge amount of fund that was spent on resource support and professional training, the effectiveness of MCE has always been subject to skepticism. There are abundant 
teaching materials for facilitating civics placed in primary schools; however, teachers do not use them conventionally. More specifically, in most primary schools, the citizenship education teaching kits are merely placed in the staff rooms but not for use by teachers. This phenomenon is considered as very inappropriate. Obviously, the teacher who is a frontline practitioner in the curriculum plays an influential role at implementation level. Therefore, the studies on teachers should receive serious attention. These are the issues that set the context for this study.

There is a distinct lack of studies on primary school teachers in MCE after the 2000 curricular reform. This research study aims to fill this gap. The first purpose of this research project is to explore primary school teachers' understanding of the current knowledge in MCE. Secondly, it attempts to find out the factors associated with teachers' attitudes towards MCE in their daily teaching. For investigating teachers' understanding of MCE, the study includes their perceptions regarding the component of MCE, the importance of five priority values and attitudes - perseverance, respect for others, responsibility, national identity and commitment as well as the needs of promoting these five priority values and attitudes in primary education. For investigating teachers' attitudes towards MCE, the study includes their degrees of concern, their receptivity towards implementing MCE and factors affecting their attitudes towards MCE in the school.

This qualitative research has enhanced further understanding of the real situation emerging across the intended curriculum and the actual practice in MCE in schools. The personal and environmental factors in affecting primary school teachers' perceptions and attitudes of MCE are revealed. The findings of the present study have significant theoretical and practical implications for professional development, teacher induction as well as curriculum development regarding MCE.

\section{Theoretical Orientation}

For decades a number of philosophers, psychologists and educators have provided considerable insight into the theoretical issues about the role of the teacher in education (Bruner, 1966; Dewey, 1902; Gagné, 1974; Grundy, 1998; Jackson, 1968; Kohlberg, 1976; Lee and Fouts, 2005; Lindsey, 1962; Piaget, 1932; Rogers, 1969; Skinner, 1974; Wayland, 1962). This section of the paper draws together the main issues surrounding the role of the teacher related to the curriculum, the students, the moral values and the citizenship education as interpreted by these scholars.

\subsection{The teacher and the curriculum}

There are various dimensions of curriculum. They can be categorised into eight groups: curriculum as content or subject matter, curriculum as discrete tasks and concepts, curriculum as a program of planned activities, curriculum as intended learning outcomes, curriculum as cultural reproduction, curriculum as an agenda for social reconstruction, curriculum as experience and curriculum as "currere" (Schubert, 1986, pp. 26-33). Whatever the characterizations of curriculum are, all of the conceptualizations of curriculum involve a certain degree of interaction between teachers and learners. Dewey (1902) emphasized the present experience of the child in education and advocated a child-centered curriculum. For the role of the teacher in implementing the curriculum, Dewey alluded that the teacher should be a facilitator of individual growth, development and self-realization:

The case is of Child. It is his present powers which are to assert themselves; his present capacities which are to be exercised; his present attitudes which are to be realized. But save as the teacher knows, knows wisely and thoroughly, the race-experience which is embodied in that thing we call the Curriculum, the teacher knows neither what the present power, capacity or attitude is, nor yet how it is to be asserted, exercised, and realized (Dewey, 1902, p. 31).

What Dewey implied was that the job of the teacher in the curriculum is to incorporate the child's past experience into teaching (Dewey, 1938). The pedagogical curriculum is merely a framework for education. The role of the teacher is not only a implementer of the curriculum but also a decision-maker (Lindsey, 1962; Wayland, 1962). Lindsey (1962) defined the role of teacher as a professional with decision-making skill. Wayland (1962) described it as a functionary in a bureaucratic to make judgments. This idea is explored further by Grundy (1998). She claimed that both teachers and students are co-developers of the curriculum. It is an unavoidable responsibility of the teacher for participating in curriculum decision-making because "the curriculum is constructed through every act of teaching" (Grundy, 1998, p. 33).

While the views of Dewey, Lindsey and Wayland underline the role of the teacher in formal curriculum, Jackson (1968) introduced an idea of the hidden curriculum that was generated from the hidden effects of the formal curriculum. This idea was used by Snyder (1970) to explain the mismatch between intended curriculum and received curriculum. He indicated that the disparate signals given to students from both the formal curriculum and the hidden curriculum would lead to confusion. It is important to exposure the hidden curriculum due to its own value (Seddon, 1983). Students are "constantly receiving information about which they are largely unaware from people who are often unaware of this transmission" (Print, 1987, p. 7). Explicitly, the teacher is a mediator to transmit the signal from the intended curriculum to students. Therefore, the teacher plays an influential role to convert messages of the hidden curriculum through the formal curriculum. It seems reasonable to conclude that the role of the teacher is more than a decision-maker in the 
hidden curriculum.

\subsection{The teacher and the student}

A review of the literature regarding the role of the teacher in pedagogy reveals that much has been written on the human behaviour and the importance satisfying psychological needs of students in the learning process. Skinner (1974) studied the relationship between stimuli and the responses of human behaviour. He proved that the existence of a reinforcing stimulus increased the probability of the operant behaviour occurring in the future, and vice versa. He also verified that an aversive stimulus resulted in a decreased probability of the operant behaviour happening in the future. In other words, a reinforcing stimulus such as encouragement could maintain the operant behaviour of the student while an aversive stimulus such as punishment could cause the extinction of the operant behaviour. This idea of reinforcement on learning contributes to effective schooling. Bruner's (1966) notion of reinforcement was based on his theory of instruction. He proposed to use more intrinsic rewards than extrinsic incentives in order to enhance students' learning motivation. The scope of Gagné's (1974) theory of instruction focused on the process of learning rather than the learning outcome. He was concerned about critical learning conditions and suggested specific teaching strategies for teacher intervention in the learning process. His theory of instruction demonstrated the ways of teaching in the classroom. For the learning process, Rogers (1969) defined significant learning in terms of facilitation. He pointed out that the qualities in the facilitator would foster significant learning. A good teacher who was the main facilitator should be real and genuine because real learning was not merely verbal learning.

These learning theories drawn out by the psychologists have two implications for the role of the teacher in regard to schooling. The first implication is that the teacher plays a key role in behaviour modification of the student. In the school, teachers can reinforce students' desirable behaviour by encouragement and extinguish their undesirable behavior by punishment or removing the reinforcing stimulus. The judgment of the teacher has a powerful impact on the student's behaviour as well as his or her learning motivation. The second implication is related to teacher quality. The quality of teaching is not merely governed by academic knowledge, the teaching skills and the empathic understanding are both the essential components of teacher's competence. Instruction technique is a sort of teaching skills. The usefulness of the theories of instruction depends on the selection of the teacher. Besides, empathic understanding is another teacher quality affecting students. Teachers should be aware of the individual difference among students. "Together, teachers and students who know each other well can develop a course of experience (curriculum) that helps to meet their needs and enrich their growth." (Schubert, 1986, p. 421) Thus, it is important for the teacher to engage in dialogue with the students during the learning process. Teachers influence students how to learn while students influence teachers how to teach. The relationship of teachers and students is interdependent.

\subsection{The teacher and the civics education}

There are various aspects to comprehend the nature of civics education. The concept and the component of civics education varies according to the source. It is problematic to define a general definition of civics education among different countries or societies. Kerr (2000) studied the nature of civics education in 16 societies and pointed out that the key elements of the context of civics education were formal curriculum, hidden curriculum, school ethos and culture. $\mathrm{He}$ also alleged that the topical nature of citizenship education should be determined according to its breadth, depth and complexity (Kerr 2002, p. 232). In Western countries, civics is closely associated with political and national education (Heater, 1992); in East Asian countries, civics is emphasized in terms of moral education (Cogan \& Morris, 2001). While humanistic education is promoted in Western countries, Confucian values are fundamental to civics education in East Asian countries (Tung, 2001). In the case of Hong Kong, moral and civic education is chiefly composed of moral education and citizenship education. The role of the teacher regarding these two components of the moral and civic education is discussed below.

According to Hansen (2001), education is a moral endeavour and the nature of teaching is a moral activity. In accordance with the cognitive theory of child development by Piaget (1932), at the transcendental stage in which children are above seven years of age, adult constraints impel children' moral realism. Children who are at this stage possess the concept that obedience to rules set by adults is a good behaviour. In order to develop the conscious realization of children's moral thought, theoretical or verbal moral reflection is an effective means of moral development (Piaget, 1932). It implies that the teacher has a role in the classroom to help the child to act and think in moral ways. Moreover, Kohlberg (1976) found out that there could be some individual differences of moral development between children even though they were at the same age. His six stages of moral judgment model explained three distinct levels of moral thought including preconventional, conventional and postconventional levels. This demands teachers to expedite the transition of children's moral thinking level from a stage to a higher stage. From Kohlberg's point of view, teachers should thoroughly comprehend the meaning of virtue since "teachers are moral educators (or miseducators) as creators of the 'hidden curriculum' of the moral climate of the classroom" (1981, Kohlberg, p. 1).

Virtue is a significant part of Confucian ethic. It has a considerable influence on the normative patterns of society and 
morality in Chinese culture (Hall \& Ames, 1987). In Confucius's Analects (1979), a large proportion of the content was written in the format of conversations between Confucius and his students. Confucius as a teacher was a domain of the conversations. The implication in this phenomenon is that the status of the teacher is relatively high in the Confucian tradition. Traditionally, it is regarded that it will be the shame of teachers if they do not instruct students severely. Under the influence of Confucianism and Chinese traditional culture, the role of the teacher is a mighty instructor who is respected widely in the society. The teacher who seems to exercise a strange power over the student plays a key role in affective education. In addition to the instinct imitation capacity of human being (Skinner, 1974), undoubtedly, the teacher is a role model of the student.

On the other hand, teachers are considered to have a double role in citizenship education. Lee and Fouts (2005) stated that teachers did not only play a passive role but also an active role in citizenship education:

They are both the recipients and the providers of citizenship education - recipients in the sense of doing what is expected of them by the society, the education body, the official curriculum and the school; providers in the sense that in actual practice they are the ones making all the decisions on what to teach and how to teach, and in determining what is important for what groups of students. Teachers thus play a key role in citizenship education (Lee \& Fouts, 2005, pp. 9-10).

Based on this view, teachers who act as the recipients of citizenship education are expected to understand the intended curriculum and grasp the contemporary knowledge of civics. As mentioned above, teachers are also the providers of citizenship education due to their frontline role in the curriculum. Therefore, the implemented curriculum of citizenship education is decided by teachers' perceptions and attitudes towards civics and morality. It seems that a study on teachers' understanding and attitudes towards moral and civic educaiton might reveal the implemented curriuclum of the moral educaiton as well as the citizenship education. This is the philosophy that underpins this study.

\section{Overview of Moral and Civic Education in Hong Kong Primary Education}

\subsection{Content of Moral and Civic Education}

According to the offical curriculum guide (Curriculum Development Council, 2002a, Booklet 3A, p. 7), Moral and Civic Education (MCE) involves eleven different themes. They are moral and ethical educaiton, civic education, life education, health education, sex education, legal education, drug education, media education, AIDS education, consumer education and environmental education. In the short-term phase of the curricular reform, five positive values and attitudes including (i) perseverance, (ii) respect for others, (iii) responsibility, (iv) national identity and (v) commitment are suggested to be focused. Schools should adopt a specific theme for MCE to develop these five priority values and attitudes. The life event approach is a teaching strategy to enhance MCE for whole-person development in the curriculum framework. For this practical approach, some recommendations of core events and extension or special events were provided as examples in the curriculum guide. The main function of its curriculum framework is to re-organize the themes of civics to avoid gaps between cross-curricular areas and values development (Curriculum Development Council, 2002a, Booklet 3A, p. 6).

In the curriculum framework, there is no concrete assessment of student learning in MCE but some principles of assessment are given. The purpose of assessment in this field is to provide useful feedback and opportunities for reflection which aims to develop students' positive values and attitudes and also their self-reflection abilities (Curriculum Development Council, 2002a, Booklet 3A, p. 21). The assessment is an interactive process involves teacher, students and their peers and parents. Thus, school heads and teachers are the key players in MCE. The curriculum guide states that the school head should establish better connections among the coordinators of civic education, sex education and environmental education as well as school discipline team and guidance team (Curriculum Development Council, 2002a, Booklet 3A, p. 18). Subject teachers also play a key role in MCE. There are seven duties or requirements. The duties or requirements of subject teachers which are mentioned in the curriculum guide are all related to their professional development regarding knowledge, understanding, skills and attitudes towards MCE. In order to give a clear conceptual framework of curricular reform for subject teachers in their professional areas, eight key learning area curriculum guides and the General Studies for primary schools curriculum guide were generated from the curriculum guide and delivered to all primary and secondary schools in 2002.

\subsection{Implementation of Moral and Civic Education}

Basically, MCE is conveyed through both formal curriulum and informal curriculum in Hong Kong primary schools. In the formal curriculum, it incorporates in General Studies (GS) in the Primary 1 to 6 school curricula. General Studies is a core subject in primary education. The content of this subject consists of three key learning areas including Technology Education, Science Education as well as Personal, Social and Humanities Education. There are six strands in the curriculum of General Studies where National Identity and Chinese Culture is one of them. "One of the major aims of GS is to help students maintain a healthy personal development and become confident, rational and responsible citizens." (Curriculum Development Council, 2002b, p. 90) The General Studies for Primary Schools Curriculum 
Guide (Primary 1 - Primary 6) (Curriculum Development Council, 2002b) is a subject curriculum guide of General Studies in primary education. It provides some teaching strategies and examples for promoting MCE through learning and teaching of General Studies. In a general way, the subject teachers implement moral and civic values usually through the medium of civic-related syllabus. For example, a sense of national identity can be nurtured to students by teaching Chinese culture or Chinese history. On the other hand, Personal Growth Education (PGE) is another formal curriculum for developing students' competencies, generic skills, positive values and attitudes in the aspect of personal, social, academic and career development. It is a part of the Comprehensive Student Guidance Service that was introduced to primary schools in 2002. Each of the learning areas is classified into three levels: junior level (Primary 1 and 2), middle level (Primary 3 and 4) and senior level (Primary 5 and 6). Personal Growth Education was a new subject to be evoked in the academic year 2002/2003. In the Personal Growth Education Revised 2004 (School Development Division of EMB, 2004), school-based Personal Growth Education is proposed to be a compulsory program from the academic year 2002/2003 in primary education with a minimum of twelve periods per school year for Primary 1 to 6 students. It indicates that "[s]chools should make flexible use of the teaching time to conduct PGE in single lessons or double lessons. Also, schools can arrange additional lessons as required to cater for students' developmental needs" (School Development Division of EMB, 2004, p. 8). Personal Growth Education is run as a school-based program. Its design varies across the culture and the actaul needs of schools but a life event approach is applied to the mode of design.

In the informal curriculum, MCE is always implemented through extra-curricular activities and pilot research schemes. In the General Studies for Primary Schools Curriculum Guide (Primary 1 - Primary 6) (Curriculum Development Council, 2002b), life-wide learning and service learning are introduced for developing the five priority values and attitudes of primary school students. Such as a visit to an eldercare center and participation in an outdoor excursion project or a voluntary organization are the typical extra-curricular activities with regard to MCE. In fact, a lot of primary schools apply for government funding to employ academic partners to assist teachers in implementing moral and civic values. The academic partners from universities or research associates take on a range of roles within the schools. They are experts in this field, and also are the facilitator in the learning and teaching process. They are also the resource providers for the schools. It is not surprising that this informal curriculum becomes a regular curriculum in most primary schools in Hong Kong. Some schools even schedule a period of weeks for the outdoor learning project to take place. Besides, interaction between teachers and students inside or outside the classrooms is also a common way to promote MCE (Curriculum Development Council, 2002b, p. 92). The school-based Personal Growth Education provides this opportunity. Class master or mistress is the teacher usually assigned in charge of the Personal Growth lessons in the class.

This short overview analyzes the contemporary situation of MCE in Hong Kong primary education. In accordance with the features of formal and informal curriculum in MCE, it seems reasonable to infer that General Studies teachers and class teachers both play their significance in primary civics education. It also identifies issues that need to be addressed as the teacher factor is an influential element in successful practice of MCE.

\section{Previous Research}

Numerous research studies focused on the performance of students in civics education. One of the significant studies in this field is an international assessment. The International Association for the Evaluation of Educational Achievement (IEA) carried out a two-phase civics education study in 1995 and 1999 respectively. In Phase one of the project, national qualitative case studies were conducted in 24 countries to examine their context and meaning of civics education. In the second phase of the project, a survey instrument was developed based upon the qualitative observations from the previous case studies to investigate civic knowledge and engagement of around 90,000 students in the usual grade for 14-year-old students from 28 countries (Torney-Purta, Lehmann, Oswald \& Schulz, 2001). Hong Kong was one of the participating countries in the entire study. Secondary 3 students were the research targets in Phase two of the study. According to the research report of the second phase of the study (Torney-Purta et al., 2001), the means of Hong Kong students' civic knowledge and attitudes towards immigrants were almost above the international means while the mean of their attitudes towards nation and their perceptions of opportunities for civic engagement in classrooms and schools was considerably below the international mean. It indicates that Hong Kong students have good citizenship knowledge and they are concerned about social-related citizenship issues but they do not favour confrontational and violent political actions (Lee, 2004). A question for future analysis is how an open classroom climate can be generated to provide students opportunities to participate in discussions of issues as well as enhance their national identity? However, the amount of research concerning the implementation of curricula in MCE and the teachers' knowledge of civics is quite small by comparison.

\subsection{Research on implementing civics education}

Hong Kong was the only Asian region to participate in the entire IEA Civic Education Study. Due to the impact of Confucianism and the traditional culture, it is supposed that "[e]ducational programs in Asian countries manifest a 
strong commitment to moral aspects of citizenship education" (Steiner-Khamsi, 2002, p. 188). This hypothesis, however, contrasts strikingly with Steiner-Khamsi's research findings. Steiner-Khamsi (2002) studied the spheres of citizenship among Hong Kong, Germany, Romania and the United States by analyzing the results of the second phase of the IEA Civic Education Study. She criticized that there was no significant commitment to the moral sphere in Hong Kong and it lacked a supportive environment for enhancing moral education in schools. She also claimed that a moral dimension of citizenship in Hong Kong schools was reflected by practices but not at the policy level. It was because the number of classes related to moral education such as religious studies or ethics in the curriculum were insufficient and they were mainly integrated within the constitutional sphere. On the other hand, in many Western countries such as Canada, England and Australia, an integrated approach is a domain of the pattern organizing citizenship education in the primary school (Kerr, 2002). Based on the findings of the IEA national case studies and the policy statements from the Institute for Numerical Computation and Analysis (INCA) Archive, Kerr (2002) used triangulation as a qualitative method to combine national policy initiative and professional circumstances on researching citizenship education in nine Western countries. He pointed out that "[t]his pattern suggest[ed] a deliberate emphasis in the intended curriculum, particularly in the early years of this phase, on children's understanding of their interaction with the world around them with respect to topics and aspects" (Kerr, 2002, p. 223).

In the mainland China, schools are encouraged to build up connections with community for promoting school-based moral education. Cheung and Pan (2006) identified that the diversified methods were applied in the state to increase institutional autonomy for improving the quality of moral education. They explained that not only the on-campus channels including curriculum and extra-curricular activities were involved in moral education but also the off-campus bodies such as museums and mass media. In fact, some pilot research projects regarding the implementation of civics education were conducted in primary and secondary schools in Hong Kong. An official research entitled Whole School Moral and Civic Education Programme for Promoting Five Priority Values investigated the effectiveness of the whole-school approach in changing school culture for promoting civics education (Moral and Civic Education Section, 2004) and a positive result was reported. Another official action research project was conducted on the basis of grounded theory by participant observations and key-informant interviews. A causal relationship between cognitive, affective and behavioural dimensions of national identity was demonstrated in the pilot study. The report indicated that co-curricular activities were effective channels for students to develop their cognitive and affective competencies in citizenship education (Moral and Civic Education Section, 2003).

Moreover, national education has particularly been concerned in Hong Kong after 1997. Cheung (2005), a Chief Curriculum Development Officer (Moral and Civic Education) of EMB, emphasized the essence of national education in the development of a sense of national identity in 2005 International Symposium on National Education. A comparative study on national identity conflicts and civic education conducted by Mátrai (2002) showed that the civics-related subjects in Hong Kong addressed a vague conception of national identity. The identity matters of the subjects in schools are mostly historical descriptions. "Historical topics also provide opportunity to strengthen cultural nation identity, but Hong Kong's typically descriptive teaching methods allow avoidance in these topics of the actual political aspects and conflicts originating from the move to one political nation."(Mátrai, 2002, p. 98) Actually, a study on enhancing the national identity of Hong Kong students has been directed recently. One of the research projects (Centre for Citizenship Education of HKIEd, 2005) as mentioned at the beginning of the paper entitled National Identity and Global Citizenship Educaiton Project was launched in three primary schools and four secondary schools from 2003 to 2005. It was an action research project for promoting national identity and global citizenship education at the schools. Apart from developing subject-based curriculum and project learning strategy, the research report also claimed that effective partnerships of moral and civic edcuation between Hong Kong schools and the schools in the mainland China has been established for those years (Centre for Citizenship Education of HKIEd, 2005). These official action research projects seem to develop productive approaches for facilitating citizenship and national education.

One remarkable aspect of the research projects on civics education reviewed above is that seldom was the study principally conducted in primary schools. Most cases of the study merely focused on secondary schools or the secondary civic curricula. However, as primary education provides a foundation education for the student, it is important to explore the implementation of civics education as well as the effectiveness of civics programs at primary level.

\subsection{Research on Hong Kong teachers in civics education}

On the basis of the findings from Phase one of the IEA Civic Education Study, Mintrop (2002) studied teachers and civics education instructions in seven societies or countries: Chinese Taipei, the Czech Republic, Finland, Italy, Hong Kong, Hungary and the United States. He ascertained that most teachers in these countries, with an exception of Finland, were not subject-matter specialists in civics education. "Knowledge in this field is constituted not by formalized or codified body of knowledge, but by the informal, personal knowledge, on-the-job craft knowledge and life experience of the instructor." (Mintrop, 2002, p. 67) Indeed, there is no special requirement for teachers to teach moral- or 
civics-related subjects in Hong Kong. MCE is not a compulsory subject in most of teacher-training programs. Thus, research on teachers' knowledge of civics is crucial in this field.

A research report pointed out that Hong Kong teachers were relatively concerned about current events of local affairs. Lee and Leung (2006) conducted a study on global citizenship education in secondary schools from December 2002 to June 2003. The research targets were the secondary school teachers in Hong Kong and Shanghai. One of the purposes of the study was to understand teachers' knowledge, skills and values towards global citizenship education. The most interesting finding of the comparative study was that teachers in Hong Kong tended to focus on local affairs and values in global citizenship education. Besides, depoliticisation was a notable feature of teachers' perceptions of citizenship which was implicated in the other comparative research. The most recent research study regarding Chinese primary and secondary school teachers' perceptions of citizenship was conducted in Hangzhou, Guangzhou and Hong Kong by Lee (2005). The research result showed that teachers in Hong Kong ranked the fulfillment of family responsibilities, the knowledge of government and current events, and the moral and ethical behaviour to be the highest priority of good citizenship characteristics (Lee, 2005, p. 227). Lee (2005) explained that it was because they perceived the term 'citizenship' as a relationship between the government and citizens but not nationality. The second reason caused the result was an affection of the political transition on teachers in Hong Kong. In comparison with teachers in Guangzhou, he classified Hong Kong teachers' perceptions of good citizenship as social citizenship with focusing on the importance of social involvement and awareness:

As indicated in the interview, teachers in Hong Kong seem to view citizenship from the social rather than the political perspective. Even political involvement such as voting is rather passively expressed. Also, there is a focus in teachers' responses on duties and civic virtues such as obeying laws; individual rights in both cities tend to receive less attention. This implies an inclination towards classical citizenship. (Lee, 2005, p. 234)

According to Lee's (2005) research findings, teachers in Hong Kong generally deemed that they had greater influence on students than the parents had. It might be one of the reasons for the teachers to treat themselves as a role model of students and take the responsibility in MCE. One of the findings related to the most helpful types of classroom activities for the students' citizenship development considered by Hong Kong teachers was activity dealing with current events (Lee, 2005, p. 239). However, Lee's (2005) report did not distinguish findings between primary and secondary school teachers. Grossman (2004) conducted a survey of teachers' perceptions of future citizens in Hong Kong and Guangzhou. He took Postgraduate Diploma in Education (PGDE) students who were in-service primary school teachers as the sample of Hong Kong. The survey showed that ability to work with others in a cooperative way and to take responsibility for one's role and duties within society was ranked to be the highest frequency citizen characteristics of teachers' perceptions of future citizens in Hong Kong; however, the item of willingness and ability to participate in politics at local, national and international levels was ranked to be the lowest priority. Observably, a reflection of teachers' perceptions of citizenship could be seen in the pedagogical approaches chosen for implementing civics education in the classroom.

In reviewing the previous research, it is obviously to note that there is a marked lack of research study concerning the importance of primary school teachers in civics and citizenship education. Most of the study targets of the former research such as that summarised above were the teachers teaching only in secondary schools or both in primary and secondary schools. Only a few research brought the primary school teachers particularly into focus. Although Grossman (2004) took in-service primary school teachers who were taking the subject of civics education as the sample for his comparative study, the purposeful sampling was merely drawn form the teacher training institution and his study only focused on teachers' perceptions of future citizens. To fill the gap in research on primary schools, this study chooses to focus on analyzing teachers' understanding and attitudes towards the official framework of primary civics education deserve researching.

\section{Methodology}

\subsection{Research Design}

In this study, a qualitative research approach was adopted. To investigate primary school teachers' understanding and attitudes towards Moral and Civic Education (MCE) in Hong Kong, interviews and document analysis were the primary methods of this study. In-depth interviews were conducted to elicit the cognitive structures leading teachers' perceptions of MCE (Marshall \& Rossman, 1995). The interview schedule comprised three parts. The first part was a set of background questions to collect some information about the length of teaching experience and the teacher training of the interviewees. The second part and the third part of the interviews were to explore teachers' understanding as well as their attitudes towards MCE respectively.

\subsection{Sampling}

A government-aided whole-day primary school was chosen for this study. It is a typical mixed gender school with Christian background. It was established in 1961 and located in a lower socioeconomic region in Hong Kong. In the 
academic year 2006/2007, there were 49 certificated teachers and 30 classes from Primary 1 to Primary 6 in the school. In order to collect data from the teachers at their different career stages in the school, the sampling was purposeful. The teachers were divided into three groups according to their length of teaching experience: teachers at the early career stage (less than 10 years teaching experience), teachers at the middle career stage (11 to 20 years teaching experience) and teachers at the late career stage (over 20 years teaching experience). A total of six teachers were invited to participate in this study. Two teachers were selected from each group for semi-structured in-depth interviews. The background information of the interviewees was summarized in Table 1. The responses obtained from the interviewees were tape-recorded and coded with categories. Concept mapping was applied for emerging themes or patterns. The findings from the study were compared to the official content of MCE and then used for analyzing.

\section{Description of Findings}

\subsection{Teachers' knowledge about moral and civic education}

Almost all interviewees viewed the term 'moral and civic education' from a moral aspect. Expect for one interviewee, Teacher C, who considered citizenship as the key message of Moral and Civic Education (MCE). The other major point of view among interviewees was that moral development of children should be the focus of MCE. Values and attitudes were also regarded as the domain in this area. Some interviewees mentioned about the importance of values and attitudes not only from a personal aspect but also from a social aspect. Teacher B and Teacher D considered social matters such as social rules and social stability to be the key messages of MCE. It indicated that teachers' general conception of MCE was a pedagogical issue regarding individual moral development for the social purpose. Although all interviewees agreed to the importance of promoting values and attitudes in MCE, none of the interviewees knew what the five priority values and attitudes were. No interviewee had any idea about the five priority values and attitudes proposed by the Curriculum Development Council. Four interviewees even did not know the shot-term phase of the 2001 curriculum reform when was from academic year 2001/2002 to academic year 2005/2006.

Teachers' understanding of MCE was insufficient. They got the notion of moral and civic values but they did not know the components of MCE. In the interviews, the teachers were requested to list some relevant issues or topics of MCE. Their responses were hence classified into eleven themes under the curriculum framework. By comparing the conceptual diagram of the curriculum framework and the answers provided by the teachers, it indicated that the teachers merely knew a small number of the themes in MCE. The result which is about interviewees' cognition in this area is shown in Table 2. Four out of six interviewees recognized that Moral and Ethical Education was a theme of MCE. Only two interviewees knew that Civic Education was one of the themes regarding MCE. Health Education and Legal Education were mentioned by two interviewees respectively. However, seven out of eleven themes which included Life Education, Sex Education, Media Education, Drug Education, AIDS Education and Consumer Education were not mentioned in the interviews. As indicated in Table 2, the teachers at the late career stage seriously lacked knowledge in MCE. One of the interviewees at this stage, Teacher E, who was a General Studies teacher and also taught Personal Growth Education, could not even recognize any issues or topics from this field. Either the teachers at the early career stage or the teachers at the middle career stage also had limited knowledge about MCE. They used to regard Moral and Ethical Education as the overall theme of MCE in Hong Kong primary education. Thus, the primary school teachers paid scanty attention to the civic component of MCE.

\subsection{Teachers' comprehension of the five priority values and attitudes}

There had some coherence of the interpretations of the terms 'perseverance, respect for others, responsibility, national identity and commitment' by all interviewees and the Curriculum Development Council. Interviewees' comprehension of the five priority values and attitudes were closest to the statements of that in the Basic Education Curriculum GuideBuilding on Strengths (Primary 1 - Secondary 3) (Curriculum Development Council, 2002a). Table 3 shows a comparison of interviewees' responses with the official interpretations of the five priority values and attitudes. Teachers' interpretations of these values and attitudes in the interviews mostly matched to the statements regarding the five priority values and attitudes by the Council. Four out of six interviewees considered perseverance to be a strength of the Chinese people such as patience and persistence. Four of the interviewees pointed out that appreciations and acceptance of different beliefs were the main idea of respect for others. And also four interviewees deemed commitment as a social value with contribution. Their points of view about perseverance, respect for others and commitment were the main idea of the official interpretations in regard with these three values and attitudes.

Nevertheless, there were some differences between interviewees' comprehension and the official interpretations of responsibility and national identity. While the interpretation of responsibility by the Council is related to both individual and community, two interviewees viewed this value only from an individual aspect. They were concerned about personal responsibility such as finished the job on students' own initiative or finished the job with certain quality rather than social responsibility. One interviewee, Teacher E, could not elaborate on her understanding of the term 'responsibility'. The other interviewees connected responsibility to the different roles in school, family and society. Besides, interviewees' comprehension of national identity was various from the official statement. The Council does not 
advocate imposing national sentiments on students, however, some of the interviewees interpreted national identity in terms of emotion. Teacher $\mathrm{C}$ tied patriotism to this value. Teacher $\mathrm{E}$ connected an expression - 'proud', which was mixed of satisfaction and pleasure, with her perception of national identity. Only one interviewee, Teacher F, referred to some activities such as flag-raising ceremonies and singing the national anthem in special events to develop students' sense of belonging to China. It is clear that some teachers did not understand these two values completely. In general, the teachers interpreted these values and attitudes according to their teaching experience as well as their own notion of the values.

\subsection{Teachers' perceptions regarding the needs of promoting the five priority values and attitudes in primary education}

All of the interviewees agreed the importance of the five values and attitudes proposed in primary education even though they had different opinions in the importance priority of these values and attitudes. Teacher D was an exception in this issue. She emphasized the same degree of importance among perseverance, respect for others, responsibility, national identity and commitment in schooling. From her point of view, there was no preferred priority for these five values and attitudes. Teacher A and Teacher B both were at their early career stage but they had opposite opinions about the general importance priority of the five values and attitudes. Teacher A regarded that national identity was a less important value to implement in primary education but Teacher B thought that national identity was the most important value for primary school students. Teacher A stated that:

Generally speaking, I think that national identity is not very important among these five priority values and attitudes. Firstly, it is difficult to nurture at primary school level. Secondly, I personally do not have a sense of national identity so that it is very hard for me to teach the related topics.

Teacher B had another view:

National education is a focus in primary education. As Hong Kong had been return to Chinese sovereignty, it is essential to develop a sense of national identity of primary school students. They should have a sense of belonging to China. It is also a purpose of promoting moral and civic education. This value is very important for our society to have a good development in the future.

It is clear that the arrangement of priority mainly depends on teachers' perceptions of the five values and attitudes. The other interviewees generally agreed the importance of the five values and attitudes proposed in primary education but did not show their preferences.

\subsection{Teachers' degree of concern and receptivity regarding moral and civic education}

All interviewees reported a certain degree of concern about MCE in terms of its importance in their daily teaching. Teacher B, Teacher C, Teacher D and Teacher F had high degree of concern about this issue due to its importance for the society. They believed that MCE in schools could generate good citizens in the future. Relatively Teacher A and Teacher E had lower degree of concern about MCE. Teacher A explained that it was because General Studies was not her major subject. The reason given by Teacher $\mathrm{E}$ of paying relatively less attention to this area was lack of time in her teaching schedule. Even though two interviewees had some difficulties on promoting MCE because of the personal and practical problems, all of them agreed that it was the duty of primary school teachers to nurture moral and civic values to students. As noted by Teacher A:

Teachers should be the role model of students because of an imitation effect. ... It is necessary to promote moral and civic education in primary schools as schooling is not only for knowledge delivery but also for the moral development of children. A student has to learn how to act as a human being.

Apart from this view, the interviewees also deemed the primary school teacher as a guide in MCE. Teacher E pointed out that students in the primary school were too young to clearly distinguish right and wrong so they needed guidance offered by teachers. Teacher D thought that MCE should be implemented to students since their childhood. The significance of the implementation of MCE at the primary school was mentioned by Teacher $\mathrm{C}$ as well:

Actually, primary school students spend a lot of time in the school. In this busy city, I personally believe that parents do not have time to nurture moral and civic values to them at home. Students generally obey their teachers at the primary school. By my experience, as I teach lower form students in this school, I find out that lower form students can assimilate these values very well when I convey moral and civic education in the class.

It seems that the interviewees had similar understanding of their roles in MCE. The interviewees understood their profound influence on students especially in primary education. They all agreed that the teacher was a key factor to facilitate MCE at the primary school level. As a consequence, it could be explained why all of the interviewees are receptive to promote $\mathrm{MCE}$ in their daily teaching. Teacher $\mathrm{C}$ stated that civics and morality were more important than academic knowledge in schooling. Teacher F also regarded MCE as the most important part in pedagogy. These are the factors associated with teachers' receptivity with regard to MCE. Obviously, the teachers have high receptivity regarding this issue. Nevertheless, not all of the interviewees could accept to develop an open learning and teaching 
culture to promote MCE. Teacher $\mathrm{C}$ was the one who could not accept to provide an open climate in the classroom to nurture moral and civic values to students because she was worried about misleading ideas raised by students:

If the student raises a wrong idea, I must correct it. I cannot stand any wrong concept expressed in the class. So, I can not really accept to develop a very open learning and teaching culture to teach moral-related topics. I think I would prefer giving my own opinions to students regarding these issues.

Although one interviewee gave a negative response, the others had positive views on developing an open learning and teaching culture to implement civic and moral education. Five of the six interviewees deemed the interaction between teachers and students as the essential medium facilitating critical thinking. Teacher A said that peer sharing was useful in value education because students could learn from others. Teacher D also agreed the importance of interaction and sharing in MCE:

The student cannot be a passive learner in this subject area. Moral and civic development is directly related to students' background. It is not related to their ages. A ten-year old student might be more mature than a fifteen-year old student due to his personal experience. Great individual differences among students exist in moral and civic education. ... As a matter of fact that the background of teachers and students is different, teachers have to provide more opportunities for students to express in order to understand them more.

From teachers' responses above, it reveals that moral and civic development of children is stressed by primary school teachers. The teachers understood and agreed the needs of promoting MCE at primary school level. They also recognized their roles in this subject matter. Thus, the teachers have a high degree of concern and receptivity regarding MCE. It implies that the attitude of the primary school teachers in Hong Kong towards MCE is generally positive and open-minded.

\subsection{Factors affecting teachers' implementation of moral and civic education}

The teachers conveyed moral and civic values to primary school students in various ways. According to teachers' responses in the interviews, the approaches or teaching materials were selected from two main areas. The first area was the formal and informal curricula. The second area was the learning and teaching environment. General Studies and Personal Growth Education were the formal curricula of MCE. Apart from these two subjects, Chinese and Bible Studies were also the major subjects for the teachers to promote MCE in the school. Some interviewees reported that they could implement these values through other subjects such as English and Physical Education. Teacher F preferred promoting moral values to all students in the school through the period of assembly. Extra-curriculum activity was another way for Teacher A, who was a leader of Girl Scout, to implement MCE. On the other hand, the learning and teaching environment also affects teachers' implementation regarding this field. Half of the interviewees were class mistresses. They had the Class Master/Mistress Period every school day to deal with student affairs such as students' behaviour problems. These interviewees agreed that this period could provide the opportunities for them to nurture moral and civic values to students. It is interesting to note that among all the interviewees, even three of them were not assigned to be the class masters or mistresses, regarded students' disciplinary problem as the teaching material or resource for them to implement MCE. In teachers' opinions, the behaviour problem of students was the main factor to arouse their self-motivation in respect of promoting MCE. As Teacher A said:

I can see that, nowadays, children are very poor in moral and civic development. They do not know how to respect others and they lack politeness with comparing children in the past generation. That is the reason why I am eager to promote moral and civic education at the school.

Besides, the personal experience of teachers is also a factor affecting their implementation of MCE. Some interviewees replied that their own experience would be the issue sharing with students in order to convey moral and civic values. Teacher $\mathrm{C}$ mentioned that:

I would like to discuss the hot topics such as the content of current television programmes with my students.... I would also like to share my experience when I talk about civic-related topics. Once I saw a passenger who had inappropriate behaviour on the train, I took it as an issue to discuss with students in the class. I think it is a kind of life event approach.

It is critical to indicate that the interviewees used to apply school events or their life events for promoting MCE but none of them mentioned about discussing social events such as political issues with students to be the instrumentation. It is obvious that the teachers emphasized moral matters and guidance in their implementation of MCE. The interviewees did not discuss any political topics with upper form primary school students. It seems that teachers in Hong Kong are not concerned with social issues. In primary schools, citizenship and politics is not the focus in MCE.

The lack of assistance is also a negative factor to affect teachers' implementation of MCE in primary schools. Teacher A and Teacher D thought that colleagues and the informal curriculum could provide limited assistance for them in this area. Four out of six interviewees did not have any assistance for them to promote MCE; by contrast they faced some 
resistances to promote MCE in the school. The greatest resistance came from the school-based curriculum. Almost all interviewees did not have enough time to implement moral and civic values to students due to their tight teaching schedules. School examination was the resistance for Teacher A. Incomplete civic curriculum was the resistance for the other interviewees. Teacher B complained that:

The curriculum does not show much concern about individual differences between students. I want to nurture some values to my students because of their special needs but unfortunately I cannot. It is because the issues are not included in the curriculum and time is not allowed. ... Undoubtedly, the curriculum of Personal Growth Education is designed for the social needs. However, it can not serve the needs of every student. This is a contradiction. Its framework really controls my teaching. ... The curriculum of General Studies does not focus too much on moral and civic education too.

Teacher $\mathrm{C}$ also had some comments on the implementation of MCE through General Studies:

In General Studies and Chinese, the content related to morality and civics is not deep enough. General Studies includes Technology Education and Science Education... I know there are some teaching kits of Life Education in the school. I guess it should be used in teaching General Studies. I also know that there are many in the Teacher Centre. However, there is no particular period for me to use these civic-related teaching materials in my teaching schedule. Besides, the schedule of General Studies is very tight. How can I use these teaching materials in the classrooms? I have got no time!

From the document analysis, the school-based curriculum of General Studies involves six main themes. These themes are Health and Life, People and Environment, Daily Science and Technology, Society and Citizenship, National Identity and Chinese Culture, and Understanding of the World. Except Daily Science and Technology is about Technology Education and Science Education, the other themes are all directly connected to MCE. In fact, there is a high proportion of civic-related topics in General Studies. According to the schedule of Personal Growth Education provided by the subject coordinator, there is nine periods in total with one period per month in the academic year 2006/2007. Obviously the amount of period is insufficient because the official recommendation of the number of Personal Growth Education period is a minimum of twelve periods per school year. Meanwhile, the teachers pay much attention to moral and value components in MCE. Under this circumstance, these are clearly controversies that have got the teachers stirred up indeed. Overall, the arrangement of school-based curriculum and teachers' perceptions of MCE are the factors affecting their implementation of this subject matter. As self-motivation is a characteristic of the teachers in implementation of morality and civics but not the force by the educational policy or the school head, the attitude of the teachers could be concluded to be enthusiastic and progressive.

\section{Conclusion and Discussion}

\subsection{Weaknesses in understanding of moral and civic education}

Focusing on the perceptions regarding the component of Moral and Civic Education (MCE), it is no doubt that teachers' knowledge of MCE was definitely insufficient. In their conception, MCE is identical to moral and ethical education. Indeed, morality and ethics involves civics component. However, the Education Commission (2000, p. 34) proposed a broad perception of MCE in the curricula reform. The content of MCE in Hong Kong is diversified. Such as Legal Education, Media Education, Drug Education, AIDS Education and Consumer Education are knowledgeable civic-related topics. They are not included in moral and ethical education. Some of the primary school teachers in Hong Kong regard Personal Growth Eduacation as entire MCE. As a matter of fact that Personal Growth Education is merely an attachment of MCE, it is principally composed of moral and ethical elements. This phenomenon can be explained by Confucian influence rather than religious orientation.

Some Confucian concepts such as virtue, self-cultivation and internal growth were mentioned frequently in the interviews; however, none of the interviews referred to Christianism although the school selected for this study had Christian background and two of them were Christians. Due to the impact of Confucianisum, the teachers in Hong Kong relatively pay more attention to morality and ethics rather than citizenship. From a multidimensional view (1998, Cogan \& Derricott), primary school teachers in Hong Kong have put emphasis upon personal citizenship rather than other dimensions of civics education. It is not a new finding on teachers' perceptions of citizenship in Hong Kong since Grossman (2004) who studied teachers' perceptions of future citizens has also got the same result in this area. Nevertheless, the teachers have mostly coherent perceptions to the interpretations of the five priority values and attitudes evoked by the Curriculum Development Council (2002a, pp. 2-4). They strongly agreed to the needs of promoting the five priority values and attitudes for primary students and immersing them in schooling. It is a pedagogical purpose advocated in the concept of quality teaching as important for providing quality learning environment to students. Teachers' comprehension of these values and attitudes implicates their expectation of the students in moral and civic development. Teachers' expectation of the students is an influential factor to affect their attitudes towards MCE at the implementation stage in primary schools.

\subsection{Strengths of attitudes towards moral and civic education}

In spite of the fact that primary school teachers in Hong Kong are weak in the content of MCE, they have high degree 
of concern and receptivity regarding the implementation of MCE. They recognize their roles and understand the needs of implementing MCE at primary school level. As discussed before, Hong Kong teachers consider the idea of moral and ethical education to be the most important part of MCE. They regard discipline training as a major component in this area. Therefore, teachers' attitudes towards MCE vary based upon their perceptions.

Looking at the factors affecting teachers' implementation of MCE, it is obviously to notice that the school-based curriculum and teachers' perceptions are the competitors of each other. It is because there is a contradiction between these two factors. While the teachers take the responsibilities to nurture moral and civic values to students, the fixed syllabi such as the curricula of General Studies and Personal Growth Education control their implementation of this aspect. Firstly, the teachers have to compete with time. They need to finish their teaching within the set schedule because General Studies is an examination-oriented subject. Secondly, the teachers have to compete with the curriculum framework. They understand the individual need of a student or a class of students but the syllabus is not flexible to allow them to take care of students' individual differences among them. It is a dilemma of the teachers about the balance of these two factors. Thus, their attitude towards MCE depends on their decision-making abilities. Even thought primary school teachers in Hong Kong face some resistances, they still have high self-motivation to implement MCE. The disciplinary problem of students always motivates the teachers to convey moral and civic values in the primary schools. Actually, the influence of teachers by students is not a new theory in pedagogy (Gordon, 1978). On the basis of these characteristics of primary school teachers in Hong Kong, it seems rational to describe their attitude towards MCE to be progressive and enthusiastic.

\section{References}

Bruner, J. S. (1966). Toward a theory of instruction. Cambridge: Belknap Press of Harvard University.

Centre for Citizenship Education of HKIEd. (2005). Research and development projects for the enhancement of civic education in Hong Kong primary and secondary schools (5 projects). [Online] Available: http://www.ied.edu.hk/cce/Eric\%20Chong\%20Project.pdf (November 30, 2006)

Cheung, K. W., \& Pan, S. Y. (2006). Transition of moral education in China: Towards regulated individualism. Citizenship teaching and learning, 2(2), 37-50.

Cheung, W. (2005). National education and cultivation of students' national identity in Hong Kong: Prospects and challenges. In Committee on the Promotion of Civic Education (Ed.), International symposium on national education summary and evaluation report (pp. 15-16). Hong Kong: Committee on the Promotion of Civic Education.

Cogan, J. J. \& Morris, P. (2001). The development of civics values: An overview. International Journal of Educational Research, 35(1), 1-123.

Cogan, J. J., \& Derricott, R. (1998). Citizenship for the $21^{\text {st }}$ century: An international perspective on education. London: Kogan Page.

Confucius. (1979). The Analects, tr. D. C. Lao. Harmondsworth: Penguin Books.

Curriculum Development Council. (2001). Learning to learn - The way forward in curriculum development. Hong Kong: Education Department.

Curriculum Development Council. (2002a). Basic education curriculum guide - Building on strengths (Primary 1 Secondary 3). Hong Kong: Education Department.

Curriculum Development Council. (2002b). General studies for primary schools curriculum guide (Primary 1 Primary 6). Hong Kong: Education Department.

Dewey, J. (1902). The child and the curriculum. Chicago: University of Chicago Press.

Dewey, J. (1938). Experience and education. New York: Macmillan.

Education Commission. (2000). Education blueprint for the 21st century, Review of education system: Reform proposals. Hong Kong: Education Commission.

Gagné, R. M. (1974). Essential of learning for instruction. Hinsdale: Dryden Press.

Gordon, P. (1978). Role of the teacher. In J. Eggleston (Ed.), Theory and practice of curriculum studies (pp. 219-225). London: Routledge \& Kegan Paul.

Grossman, D. L. (2004). Teachers' perceptions of future citizens in Hong Kong and Guangzhou. In W. O. Lee, D. L. Grossman, K. J. Kennedy, \& G. P. Fairbrother (Eds.), Citizenship education in Asia and the Pacific (pp. 215-238). Hong Kong: Comparative Education Research Centre, The University of Hong Kong.

Grundy, S. (1998). The curriculum and teaching. In E. Hatton (Ed.), Understanding teaching - Curriculum and the social context of schooling (pp. 27-37). Sydney: Harcourt Brace. 
Hall, D. L. \& Ames, R. T. (1987). Thinking through Confucius. Albany: State University of New York Press.

Hansen, D. T. (2001). Teaching as a moral activity. In V. Richardson (Ed.), Handbook of Research on Teaching (pp. 826-857). Washington: AERA.

Heater, D. (1992). The history of the concept of citizenship. Curriculum, 13(3), 149-157.

Jackson, P. W. (1968). Life in classrooms. New York: Holt, Rinehart\& Winston.

Kerr, D. (2000). Citizenship education: An international comparison across 16 countries. Paper presented at AERA Annual Meeting, New Orleans, April.

Kerr, D. (2002). An International review of citizenship in the curriculum. In G. Steiner-Khamsi, J. Torney-Purta, \& J. Schwille (Eds.), New paradigms and recurring paradoxes in education for citizenship: An international comparison (pp. 207-237). London: JAI.

Kohlberg, L. (1976). Moral stages and moralization: The cognitive developmental approach. In T. Lickona (Ed.), Moral development and behaviour: Theory, research, and social issues (pp. 31-53). New York: Holt, Rinehart \& Winston.

Kohlberg, L. (1981). The philosophy of moral development. San Francisco: Harper \& Row.

Lee, W. O. \& Fouts, J. T. (2005). Cross-national citizenship study: Background and methodology. In W. O. Lee \& J. T. Fouts (Eds.), Education for social citizenship (pp. 3-17). Hong Kong: Hong Kong University Press.

Lee, W. O. (2004). Students' concepts and attitudes toward citizenship: the case of Hong Kong. International Journal of Education Research, 39(6), 591-607.

Lee, W. O. (2005). Teachers' perceptions of citizenship in China. In W. O. Lee, \& J. T. Fouts (Eds.), Education for social citizenship (pp. 209-246). Hong Kong: Hong Kong University Press.

Lee, W. O., \& Leung, S. W. (2006). Global citizenship education in Hong Kong and Shanghai secondary schools: Ideals, realities and expectations. Citizenship teaching and learning, 2(2), 68-84.

Lindsey, M. (1962). Decision-making and the teacher. In A. H. Passow (Ed.), Curriculum crossroads: A report of a curriculum conference (pp. 27-40). New York: Teachers College Press.

Marshall, C, \& Rossman, G. B. (1995). Designing qualitative research. Thousand Oaks: SAGE.

Mátrai, Z. (2002). National identity conflicts and civic education: A comparison of five countries. In G. Steiner-Khamsi, J. Torney-Purta, \& J. Schwille (Eds.), New paradigms and recurring paradoxes in education for citizenship: An international comparison (pp. 85-104). London: JAI.

Mintrop, H. (2002). Teachers and civic education instruction in cross-national comparison. In G. Steiner-Khamsi, J. Torney-Purta, \& J. Schwille (Eds.), New paradigms and recurring paradoxes in education for citizenship: An international comparison (pp. 61-83). London: JAI.

Moral and Civic Education Section. (2003). Collaborative research and development 'seed' projects (2002-2003): Co-curricular activities to develop students national identity in primary and secondary schools in Hong Kong. Hong Kong: Education Department.

Moral and Civic Education Section. (2004). Collaborative research and development'seed'projects (2003-2004): A whole school moral and civic education (MCE) programme for promoting five priority values - Final report. Hong Kong: Education Department.

Piaget, J. (1932). The moral judgement of the child. London: Routledge \& Kegan Paul.

Print, M. (1987). Curriculum development and design. Sydney: Allen \& Unwin.

Rogers, C. R. (1969). Freedom to learn: A view of what education might become. Columbus: Merrill.

School Development Division of EMB. (2004). Personal Growth Education Revised 2004. Hong Kong: EMB.

Schubert, W. H. (1986). Curriculum: Perspective, paradigm, and possibility. New York: Macmillan.

Seddon, T. (1983). The hidden curriculum: An overview. Curriculum Perspectives, 3(1), 1-6.

Skinner, B. F. (1974). About behaviourism. London: Jonathan Cape.

Snyder, B. R. (1970). The hidden curriculum. New York: Knopf.

Steiner-Khamsi, G. (2002). Spheres of citizenship. In G. Steiner-Khamsi, J. Torney-Purta, \& J. Schwille (Eds.), New paradigms and recurring paradoxes in education for citizenship: An international comparison (pp. 179-206). London: JAI.

Torney-Purta, J., Lehmann, R., Oswald, H. \& Schulz, W. (2001). Citizenship and education in twenty-eight countries: Civic knowledge and engagement at age fourteen. Amsterdam: International Association for the Evaluation of 
Educational Achievement (IEA).

Tung, E. (2001). Teacher development and affective education. Educational Research Journal, 16(1), 51-68.

Wayland, S. R. (1962). The teacher as decision-maker. In A. H. Passow (Ed.), Curriculum crossroads: A report of a curriculum conference (pp. 41-52). New York: Teachers College Press.

Table 1. Summary of the interviewees' background information

\begin{tabular}{|c|c|c|c|c|c|c|}
\hline \multirow[b]{2}{*}{ Career stage } & \multirow[b]{2}{*}{ Teacher } & \multicolumn{2}{|c|}{ Years of teaching } & \multicolumn{2}{|c|}{ Subject teacher } & \multirow{2}{*}{$\begin{array}{l}\text { Teacher training related to } \\
\text { MCE* }^{*}\end{array}$} \\
\hline & & in total & $\begin{array}{l}\text { at this } \\
\text { school }\end{array}$ & GS* & PGE* & \\
\hline \multirow{2}{*}{$\begin{array}{l}\text { Early career stage } \\
\text { (less than } 10 \text { years } \\
\text { teaching experience) }\end{array}$} & A & 2.5 & 2.5 & Yes & Yes & Nil \\
\hline & B & 9.5 & 3.5 & Yes & Yes & $\begin{array}{c}\text { Workshops by academic } \\
\text { organizations }\end{array}$ \\
\hline \multirow{2}{*}{$\begin{array}{l}\text { Middle career stage } \\
\text { (11 to } 20 \text { years } \\
\text { teaching experience) }\end{array}$} & $\mathrm{C}$ & 11.5 & 4.5 & Yes & Yes & Certificate of Education \\
\hline & $\mathrm{D}$ & 13.5 & 3.5 & No & No & Certificate of Education \\
\hline \multirow{2}{*}{$\begin{array}{l}\text { Late career stage } \\
\text { (over } 20 \text { years } \\
\text { teaching experience) }\end{array}$} & $\mathrm{E}$ & 24.5 & 17.5 & Yes & Yes & Seminars by EMB \\
\hline & $\mathrm{F}$ & 34.5 & 34.5 & No & No & Nil \\
\hline
\end{tabular}

Note * GS: General Studies, PGE: Personal Growth Education, MCE: Moral and Civic Education

Table 2. Teachers' cognition of the themes in MCE

\begin{tabular}{|c|c|c|c|c|c|c|}
\hline $\begin{array}{c}\text { Themes in MCE } \\
\text { (Curriculum Development Council, } \\
\text { 2002a, Booklet 3A, p. 7) }\end{array}$ & Teacher A & Teacher B & Teacher C & Teacher D & Teacher E & Teacher F \\
\hline Moral and Ethical Education & $\checkmark$ & & $\checkmark$ & $\checkmark$ & & $\checkmark$ \\
\hline Civic Education & $\checkmark$ & & $\checkmark$ & & & \\
\hline Life Education & & & & & & \\
\hline Health Education & & $\checkmark$ & & & & \\
\hline Sex Education & & & & & & \\
\hline Legal Education & & & $\checkmark$ & & & \\
\hline Media Education & & & & & & \\
\hline Drug Education & & & & & & \\
\hline AIDS Education & & & & & & \\
\hline Consumer Education & & & & & & \\
\hline Environmental Education & & & & & & \\
\hline
\end{tabular}


Table 3. Comparison of the Curriculum Development Council (CDC) and the samples with the interpretations of the five priority values and attitudes

\begin{tabular}{|c|c|c|c|c|c|}
\hline $\begin{array}{l}5 \text { Priority } \\
\text { Values \& } \\
\text { Attitudes }\end{array}$ & Perseverance & $\begin{array}{l}\text { Respect for } \\
\text { Others }\end{array}$ & Responsibility & National Identity & Commitment \\
\hline $\begin{array}{l}\text { Curriculum } \\
\text { Development } \\
\text { Council } \\
\text { (2002a, } \\
\text { Booklet 3A, } \\
\text { p. 2-4) }\end{array}$ & $\begin{array}{l}\text { a strength of } \\
\text { the Chinese } \\
\text { people } \\
\text { - face life's } \\
\text { challenges } \\
\text { cope with } \\
\text { adversities }\end{array}$ & $\begin{array}{l}\text { appreciate } \\
\text { and tolerate } \\
\text { views and } \\
\text { beliefs } \\
\text { different } \\
\text { from their } \\
\text { own }\end{array}$ & $\begin{array}{l}\text { well-being of } \\
\text { an individual } \\
\text { is inextricably } \\
\text { bound up with } \\
\text { the collective } \\
\text { well-being of } \\
\text { the community }\end{array}$ & $\begin{array}{l}\text { a deeper } \\
\text { understanding } \\
\text { of the history } \\
\text { and culture of } \\
\text { our motherland } \\
\text { enhance their } \\
\text { interests in and } \\
\text { concern for the } \\
\text { development of } \\
\text { today's China }\end{array}$ & $\begin{array}{l}\text { a basic } \\
\text { attitude for } \\
\text { the } \\
\text { realisation of } \\
\text { core personal } \\
\text { and social } \\
\text { values }\end{array}$ \\
\hline Teacher A & $\begin{array}{l}\text { patience* } \\
\text { never give up* }\end{array}$ & $\begin{array}{l}\text { get along } \\
\text { well with } \\
\text { others }\end{array}$ & $\begin{array}{l}\text { to finish the } \\
\text { job on } \\
\text { students' own } \\
\text { initiative }\end{array}$ & $\begin{array}{l}\text { recognition of } \\
\text { China }\end{array}$ & $\begin{array}{l}\text { to serve } \\
\text { others in the } \\
\text { society* }\end{array}$ \\
\hline Teacher B & $\begin{array}{l}\text { to cope with } \\
\text { pressure* }^{*}\end{array}$ & \begin{tabular}{|l|} 
\\
to appreciate \\
others
\end{tabular} & $\begin{array}{l}\text { to finish the } \\
\text { job with } \\
\text { certain quality }\end{array}$ & $\begin{array}{l}\text { a sense of } \\
\text { belonging to } \\
\text { China* }\end{array}$ & - citizenship* \\
\hline Teacher C & $\begin{array}{l}\text { persistence* } \\
\text { cope with } \\
\text { difficulties* } \\
\text { - to spare no } \\
\text { efforts }\end{array}$ & $\begin{array}{l}\text { to accept } \\
\text { different } \\
\text { opinions* }\end{array}$ & $\begin{array}{l}\text { to finish the } \\
\text { job in different } \\
\text { roles* }\end{array}$ & $\begin{array}{l}\text { patriotism } \\
\text { - a sense of } \\
\text { belonging to } \\
\text { China* }\end{array}$ & $\begin{array}{l}\text { individual } \\
\text { preparation } \\
\text { for the } \\
\text { future* } \\
\text { contribution } \\
\text { to the society } \\
\text { and the } \\
\text { country* }\end{array}$ \\
\hline Teacher D & $\begin{array}{l}\text { 'Never say } \\
\text { die'* }\end{array}$ & $\begin{array}{l}\text { to accept } \\
\text { different } \\
\text { religions, } \\
\text { beliefs and } \\
\text { races* }\end{array}$ & $\begin{array}{l}\text { to commit in } \\
\text { different } \\
\text { roles* }\end{array}$ & $\begin{array}{l}\text { understanding } \\
\text { of our } \\
\text { motherland* } \\
\text { recognition of } \\
\text { Chinese as our } \\
\text { nationality* }\end{array}$ & $\begin{array}{l}\text { commitment } \\
\text { in school, } \\
\text { family and } \\
\text { society* }\end{array}$ \\
\hline Teacher E & $\begin{array}{l}\text { self- } \\
\text { confidence }\end{array}$ & $\begin{array}{l}\text { self- } \\
\text { cultivation }\end{array}$ & (Nil) & $\begin{array}{l}\text { respect to China } \\
\text { to be proud of } \\
\text { China } \\
\text { a sense of } \\
\text { belonging to } \\
\text { China* }\end{array}$ & - a promise \\
\hline Teacher F & $\begin{array}{l}\text { persistence* } \\
\text { not to concede } \\
\text { defeat* } \\
\text { keep trying } \\
\text { after failure* } \\
\text { insistent on } \\
\text { learning }\end{array}$ & $\begin{array}{l}\text { to accept } \\
\text { different } \\
\text { opinions* }\end{array}$ & $\begin{array}{l}\text { to play } \\
\text { different } \\
\text { roles* }\end{array}$ & $\begin{array}{l}\text { flag-raising } \\
\text { ceremony* } \\
\text { to sing the } \\
\text { national } \\
\text { anthem* }\end{array}$ & $\begin{array}{l}\text { to participate } \\
\text { on students' } \\
\text { own } \\
\text { initiative }\end{array}$ \\
\hline
\end{tabular}

Note * Ideas that are coherent to the statements of CDC are printed in italics. 